\title{
BIOLOGICAL ASPECTS OF THE TRUE SPIDER KOCHIURA AULICA (ARANEIDA: THERIDIIDAE) REARED ON THE FIRST LARVAL STAGE OF SPODOPTERA LITTORALIS IN EGYPT
}

\author{
Amal E. Abo-zaed \\ Plant Protection Institute, A.R.C., Dokki, Giza, Egypt \\ Received: Mar. 28 , 2019 \\ Accepted: May. 22, 2019
}

\begin{abstract}
Specimens of Kochiura aulica spider were collected from cotton crops in Qalyubia governorate during season 2017. Spiders were associated with the leaf cotton worm, Spodoptera littoralis (Boisduval, 1833) larvae. The spider Kochiura aulica (C.L. Koch, 1838) had 5 spiderlings for female and male. Individuals of the spider $K$. aulica were reared on the first larval stage of $S$. littoralis under laboratory conditions at three constant temperatures $\left(20,25\right.$ and $30^{\circ} \mathrm{C}$ and $60-70 \%$ R.H). The first spiderling recorded the longest duration compared to other spiderlings of female and male when fed on $1^{\text {st }}$ larval stage of $S$. littoralis at three constant temperatures. Results indicate that individuals of $K$. aulica which were reared at $30^{\circ} \mathrm{C}$ developed faster than those reared at 20 and $25^{\circ} \mathrm{C}$. The life cycle of $\mathrm{K}$. aulica was the shortest when the spider reared at $30^{\circ} \mathrm{C}$ averaged 79.3 and 76.2 days followed by $25^{\circ} \mathrm{C}$ averaged 103 and 98.3 days and the longest values was 123.7 and 118.2 days at $20^{\circ} \mathrm{C}$ for female and male, respectively with significant differences among the three constant temperatures. Prey consumption was calculated for different stages. Effect of constant temperatures on longevity, life span and fecundity of the spider were studied. The number of consumed preys was the highest at $30^{\circ} \mathrm{C}$ and the lowest at $20^{\circ} \mathrm{C}$. Also, the number of egg sacs per female was the highest at $30^{\circ} \mathrm{C}$ and the lowest at $20^{\circ} \mathrm{C}$.
\end{abstract}

Key words: Theridiidae, biology, food consumption, Spodoptera littoralis, spider.

\section{INTRODUCTION}

Spiders are one of the more diverse arthropod taxa, ranking $7^{\text {th }}$ class in global diversity, which makes them a fascinating group to study (Coddington and Levi, 1991). True spiders are worldwide distributed and occupy many ecological environments. Taxonomists documented about 117 families, 4128 genera and 48086 species (World Spider Catalog, 2019).

Spiders are the most widespread of the predators, often they exist in any place, in particular in the agricultural ecosystem where they are beneficial in the reduction of the population density of the pests (Ghabbour et al., 1999); they devour any small arthropods. Thus they can play an important role in the control of the pests. Spiders consider from the biocontrol agents they fed on most of pests of vegetables, crops, ornamental and orchard trees (Jeppson et al., 1975).

Kochiura aulica was primarily described as Theridion aulicum by C.L. Koch in 1838, transferred to Kochiura by Archer in 1950, then to Anelosimus by Levi in 1956, and restored to Kochiura again by Agnarsson (2004). This spider was recorded from different governorates of Egypt (El-Hennawy, 2002 and Sallam, 2002).

Spodoptera littoralis (Boisduval, 1833) (Lepidoptera: Noctuidae), is one of the most destructive agricultural lepidopteron pests within its subtropical and tropical range. It is attacking plants belonging to 44 different families including grasses, vegetables, crops and deciduous fruit trees all containing 
species of highly economic importance (Abdel-Megeed, 1975). Many researchers studied the biological aspects of some spiders as biological control agents for many pests (Rahil and Hanna, 2001; ElErksousy et al., 2002; Hussein et al., 2003; Abdel-Karim, et al.,2006; Ahmad et al., 2009; Abdel-Azim, 2014; Ahmad and Heikal, 2016) .

This study conducted to investigate the potential and biological parameters of spider $K$. aulica reared on the first larval stage of $S$. littoralis under laboratory conditions.

\section{MATERIAL AND METHODS} Rearing of prey insect $S$. littoralis:

Cotton leaf worm, S. littoralis was reared in the laboratory using a method described by Mostafa (1988). Fieldcollected egg batches of $S$. littoralis were cultured on castor bean leaves Ricinus communis L., in glass jars, $20 \mathrm{~cm}$ diameter and $15 \mathrm{~cm}$ height, which were washed in running water and dried before being placed in rearing jars. The jars were covered with muslin cloth held in position by rubber bands and kept in an incubator at $25^{\circ} \mathrm{C}$ and $60-70 \%$ R.H. The jars were daily examined. Adult moths were confined in glass chimneys as oviposition cages. These oviposition cages were provided with pieces of cotton soaked in $10 \%$ sugar solution for adult nourishment. The obtained eggs were re-cultured as mentioned above. The batches were left until hatch and the first larval instars were taken as preys to the spider.

\section{Stock culture and mass rearing of K. aulica:}

Ten adult females of $K$. aulica were collected on 10 June 2017 from cotton crop, Kaha city, Qalyubia govemorate, Egypt. It was reared individually inside a plastic vials, fed until laid egg sacs and observed till hatching. Every female laid an egg sac, the newly hatched spiderlings were feed on $1^{\text {st }}$ larva of $S$. littoralis. Each spiderling was supplied with a known number of the prey and observed till reached maturity. These experiments were carried out in an incubator at three constant temperatures $\left(20,25,30^{\circ} \mathrm{C}\right.$ and $60-70 \%$ R.H.) Spider individuals were examined every two days and the numbers of consumed prey individuals were recorded and replaced by another live one.

\section{Biological aspects:}

Biological aspects of $K$. aulica were studied as follows: feeding behavior, spiderling duration (days), food consumption (preys/spider/day), mating, life cycle, longevity and life span of spider females and males. Also, the preoviposition, oviposition and postoviposition periods (in days), number of egg sac/female and total number of eggs/sac of the spider females were estimated.

Statistical analysis: One way Anova was calculated by using SAS statistical software (SAS Institute, 2010). In addition, LSD (Fisher's Significant Difference Test) was chosen to identify the significant difference within group.

\section{RESULTS AND DISCUSSION Behavior of mating:}

The adult female of Kochiura aulica was fed about 24 hours before introducing the male into the same glass container. The male moved towards female's web jerking his pedipalps until reaching it. Then, he touched the tips of the female's legs and pedipalps. A preparatory period preceded copulation.

\section{Behavior of feeding:}

The spider $K$. aulica attacked $S$. littoralis larva from the inter-secutar 
membrane between head and thorax, then sucked its contents.

\section{Duration of $K$. aulica Incubation period:}

The egg sac was spherical in shape, pale white and became dark before hatching. As shown in Table (1) the incubation period of $K$. aulica eggs lasted 24.7, 19.7 and 15.3 days for the females and males which fed on $1^{\text {st }}$ instars larva of $S$. littoralis at temperatures 20,25 and $30^{\circ} \mathrm{C}$, respectively. These data are confirmed by that of Abdel-Azim (2014) who indicated that the incubation period of Theridion melanostictum eggs was averaged as $\mathbf{2 4 . 5}$ days. In addition, AbdelKarim et al. (2006) found that the incubation period was lasted 13 days in individual and group rearing, moreover there were significant differences among the three constant temperatures on the egg hatchability.

\section{Spiderling duration:}

The obtained results in Table (1) revealed that $K$. aulica has 5 spiderlings for female and male. The first spiderling of $K$. aulica fed on $1^{\text {st }}$ instars of $S$. littoralis lasted 22.3, 18.7 and 14.7 days for female and 19.7, 18.3 and 14.2 days for male at temperatures 20,25 and $30^{\circ} \mathrm{C}$, respectively. The $2^{\text {nd }}$ spiderling averaged 19.3, 16.7 and 13.7 days for female and averaged 18.3, 16 and 13.7 days for male at temperatures 20,25 and $30^{\circ} \mathrm{C}$, respectively. In the same vein the $5^{\text {th }}$ spiderling lasted $18.7,15.7$ and 11.3 days for female and 18.8, 14.3 and 11 days for male at temperatures 20,25 and $30^{\circ} \mathrm{C}$, respectively.

Thus, the total immature stages lasted 99, 83.3, 64 days for female and 93.5, 78.7 and 60.8 days for male at the same constant temperatures. Statistical analysis of data showed that, when the individuals fed on $1^{\text {st }}$ instars larva of $S$. littoralis the duration of spiderling and the life cycle was affected by the degree of temperature, where high significant differences were recorded. The shortest period was recorded with the individuals fed on prey at $30^{\circ} \mathrm{C}$ while the longest period was recorded at $20^{\circ} \mathrm{C}$.

The life cycle duration at temperatures 20,25 and $30^{\circ} \mathrm{C}$, recorded 123.7, 103 and 79.3 days for female; moreover it recorded 118.2, 98.3 and 76.2 days for male, respectively. Generally, there were significant differences among the three constant temperatures on all stages of spider duration.

The obtained results are in harmony with that detected by El-Erksousy et al. (2002) who demonstrated that total duration of male life cycle was shorter than that of female, when studied the biological aspects of the spider $A$. aulicus Koch on $S$. littoralis. Total spiderlings of male and females lasted $51.1 \pm 1.6$ and $57.5 \pm 2.7$ days for males and females, respectively when Theridion melanostictum fed on S.littoralis (AbdelAzim, 2014). Also, Abdel-Karim et al. (2006) indicated that life cycle of the same species in individual rearing was 36.83 \& 39.78 days for female and male, respectively feeding on S. littoralis. Also he added that the constant temperature and humidity during rearing had an evident effect on life cycle duration. Also, the kind of prey affected life cycle duration.

\section{Longevity and life span:}

The longest life span of Kochiura aulica lasted 240.3 and 144.8 days at $20^{\circ} \mathrm{C}$ while, it recorded the shortest period as 164.8 and 99.8 days $30^{\circ} \mathrm{C}$, with significant differences among the three constant temperatures (Table 1). These results are in accordance with that of Abdel-Karim et al., (2006) who observed that the constant temperature and 


\begin{tabular}{|c|c|c|c|c|c|c|c|c|c|c|c|}
\hline \multicolumn{2}{|c|}{ ஸे } & $\underset{\text { i }}{\text { ¿ }}$ & ڤ̆ & $\underset{\text { I }}{\text { ¿ }}$ & 令 & 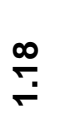 & $\begin{array}{l}\text { U్ } \\
0\end{array}$ & $\stackrel{\stackrel{N}{N}}{\text { N }}$ & $\begin{array}{c}\mathfrak{N} \\
\text { N }\end{array}$ & $\begin{array}{l}\stackrel{\circ}{\text { ஸे }} \\
\text { N }\end{array}$ & $\begin{array}{c}\stackrel{\infty}{N} \\
\text { m }\end{array}$ \\
\hline \multirow{3}{*}{ 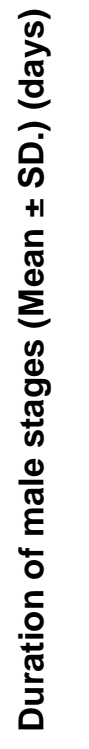 } & $\begin{array}{l}0 \\
\text { Oे } \\
\text { Oे }\end{array}$ & 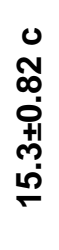 & 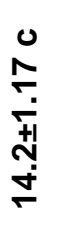 & 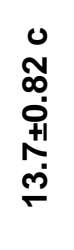 & 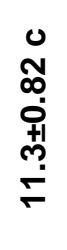 & 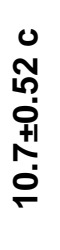 & $\begin{array}{l}0 \\
\dddot{0} \\
0 \\
0 \\
+1 \\
0 \\
-1\end{array}$ & 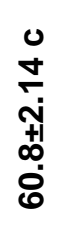 & 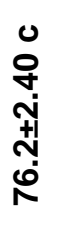 & 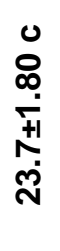 & 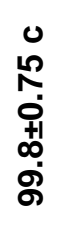 \\
\hline & $\begin{array}{l}\text { O } \\
\text { in }\end{array}$ & 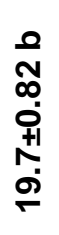 & 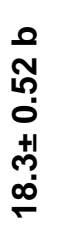 & $\begin{array}{l}0 \\
0 \\
0 \\
0 \\
0 \\
+1 \\
0 \\
0 \\
0\end{array}$ & 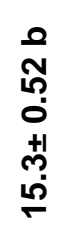 & 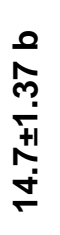 & 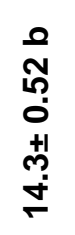 & 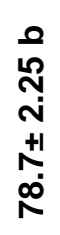 & 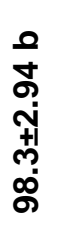 & $\begin{array}{l}\tilde{\sigma} \\
\stackrel{2}{m} \\
\stackrel{-1}{+} \\
+1 \\
\stackrel{-1}{m} \\
-1\end{array}$ & 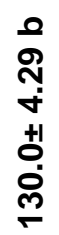 \\
\hline & $\begin{array}{l}\text { U } \\
\text { ○े }\end{array}$ & 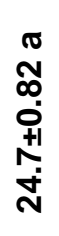 & 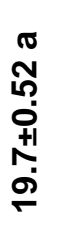 & 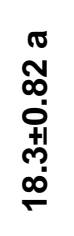 & 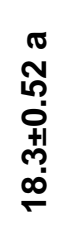 & 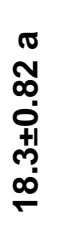 & $\begin{array}{l}\sigma \\
-1 \\
-1 \\
0 \\
+1 \\
\infty \\
\infty \\
\infty \\
\rightarrow\end{array}$ & 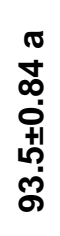 & 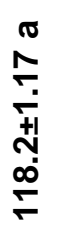 & 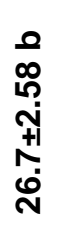 & 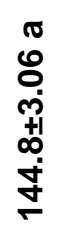 \\
\hline \multicolumn{2}{|c|}{ "ِ } & 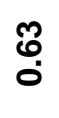 & $\begin{array}{l}\text { N } \\
\text { i }\end{array}$ & $\underset{\text { i }}{\stackrel{8}{0}}$ & $\stackrel{\circ}{\stackrel{-}{\rightarrow}}$ & $\underset{\text { m్ }}{\sim}$ & đ̊ & $\begin{array}{l}\stackrel{0}{-1} \\
m\end{array}$ & 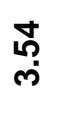 & 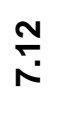 & ने \\
\hline \multirow{3}{*}{ 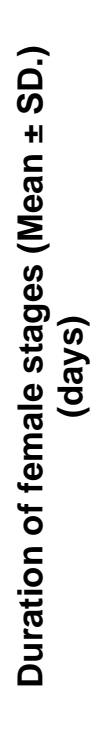 } & $\begin{array}{l}\text { U } \\
\text { Oे }\end{array}$ & 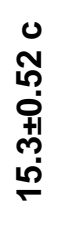 & 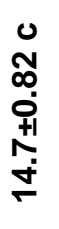 & 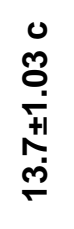 & $\begin{array}{l}0 \\
-1 \\
N \\
-1 \\
+1 \\
\stackrel{-1}{-1}\end{array}$ & 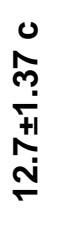 & 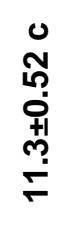 & $\begin{array}{l}0 \\
\infty \\
\infty \\
\infty \\
\oplus \\
+1 \\
+1 \\
\dot{0}\end{array}$ & 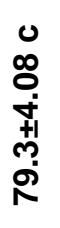 & 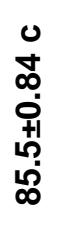 & 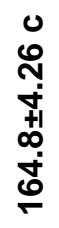 \\
\hline & $\begin{array}{l}\text { U } \\
\stackrel{\circ}{N}\end{array}$ & 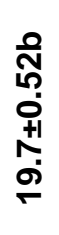 & 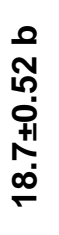 & 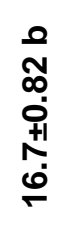 & 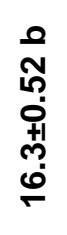 & 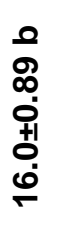 & 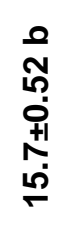 & 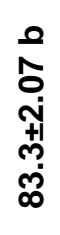 & 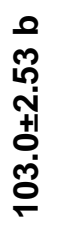 & 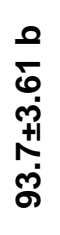 & $\begin{array}{l}0 \\
0 \\
0 \\
0 \\
+1 \\
+1 \\
0 \\
0 \\
\text { ஸे }\end{array}$ \\
\hline & $\begin{array}{l}\text { U } \\
\text { ¿ }\end{array}$ & 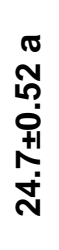 & 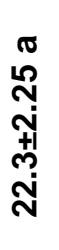 & 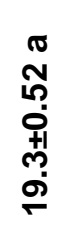 & 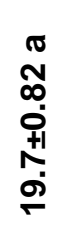 & 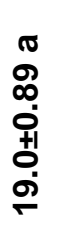 & 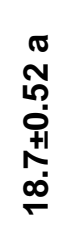 & $\begin{array}{l}\pi \\
\hat{0} \\
-i \\
+1 \\
0 \\
\dot{0}\end{array}$ & 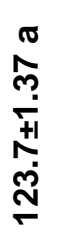 & $\begin{array}{l}\sigma \\
-1 \\
\text { m } \\
o \\
+1 \\
+1 \\
0 \\
\rightarrow \\
7\end{array}$ & 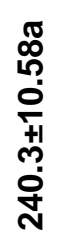 \\
\hline \multicolumn{2}{|c|}{$\begin{array}{l}\frac{0}{0} \\
\frac{d}{0} \\
\frac{0}{0} \\
\frac{\pi}{0} \\
\frac{0}{0} \\
\frac{0}{0}\end{array}$} & 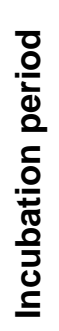 & 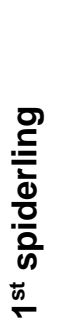 & 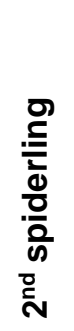 & $\begin{array}{l}\frac{D}{5} \\
\frac{5}{2} \\
\frac{0}{0} \\
\frac{0}{2} \\
\frac{0}{m}\end{array}$ & 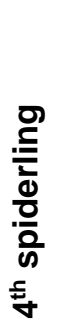 & 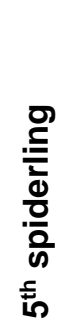 & 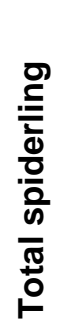 & 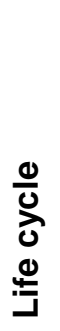 & 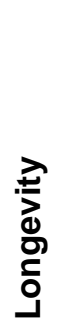 & 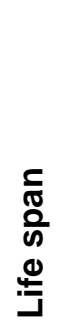 \\
\hline
\end{tabular}


humidity during rearing had an evident effect on life cycle duration. Also, the kind of prey affected life cycle and life span duration. While, Ahmad and Heikal (2016) indicated that the life span lasted on $160.17 \pm 2.04$ and $155.27 \pm 8.88$ days for male and female, respectively.

The longest female pre-oviposition, oviposition and post-oviposition periods averaged 26.7, 63.3 and 26.7 days at $20^{\circ} \mathrm{C}$, whereas, it averaged shortest period as $15.8,50$ and 19.7 days at $30^{\circ} \mathrm{C}$. Appling the same tests as shown in (Table 2), it was shown that the shortest period of female longevity lasted 85.5 days when reared at $30^{\circ} \mathrm{C}$, while longest period lasted 116.7 days, at $20^{\circ} \mathrm{C}$. Whereas the shortest period of male longevity as 23.7 days at $30^{\circ} \mathrm{C}$ and longest period as 31.7 days at $25^{\circ} \mathrm{C}$, with significant different between the three constant temperatures (Table 1). These results run with that published by Hussein et al. (2003) who revealed that adult male and female lived for longer period when reared on Tetranychus urticae Koch, Aphis craccivora Koch diets in spring-summer it averaged 73.10 \& 144.00 days compared by 60.00 \& 122.00 days when only fed on aphids.
Fecundity of the females:

The results in Table (2) indicated that, the average number of egg sac per female of Kochiura aulica fed on $S$ littoralis larvae, was $2.5 \pm 0.55$ when reared at $20^{\circ} \mathrm{C}$ and $3.5 \pm 0.55$ when reared at $25^{\circ} \mathrm{C}$, whereas the highest values was record at $30^{\circ} \mathrm{C}$ as $4.2 \mathrm{egg}$ sac per female. In addition, the average number of individuals emerged from the egg sac was 14.7, 22.7 and 28.3 when fed at 20, 25 and $30^{\circ} \mathrm{C}$, respectively with significant differences among the three constant temperatures.

This is comparable to that achieved by Rahil and Hanna (2001) who show that the adult females of $K$. aulicus Koch spider consumed large number of prey than males. Also, the same authors indicated that the oviposition period of $K$. aulicus was 28-96 days for female that mated more than once. The pre-and postoviposition periods were 9-16 and 51-210 days, respectively. However, AbdelKarim et al., (2006) reported that egg sacs per female per day during the first 20 days of oviposition period in individual rearing was $3.00 \mathrm{egg}$ sacs while in group rearing it was 0.91 egg sacs, feeding on S. littoralis.

Table (2): Longevity and fecundity of female spider Kochiura aulica when fed on first larval stage of Spodoptera littoralis at three constant temperatures

\begin{tabular}{|c|c|c|c|c|}
\hline \multirow[t]{2}{*}{ Biological aspects } & \multicolumn{3}{|c|}{$\begin{array}{l}\text { Duration of different stages (days) (Mean } \pm \\
\text { SD.) }\end{array}$} & \multirow{2}{*}{$\begin{array}{l}\text { L.S.D at } \\
0.05\end{array}$} \\
\hline & $20^{\circ} \mathrm{C}$ & $25^{\circ} \mathrm{C}$ & $30^{\circ} \mathrm{C}$ & \\
\hline Pre-oviposition period & $26.7 \pm 2.58 \mathrm{a}$ & $19.0 \pm 0.89 \mathrm{~b}$ & $15.8 \pm 0.75 \mathrm{c}$ & 2.01 \\
\hline Oviposition period & $63.3 \pm 6.83 \mathrm{a}$ & $55.0 \pm 4.47 \mathrm{~b}$ & $50.0 \pm 0.89 \mathrm{~b}$ & 5.83 \\
\hline Post-oviposition period & $26.7 \pm 2.85 \mathrm{a}$ & $19.7 \pm 0.52 \mathrm{~b}$ & $19.7 \pm 1.03 \mathrm{~b}$ & 2.0 \\
\hline Longevity & $116.7 \pm 9.31 \mathrm{a}$ & $93.7 \pm 3.61 \mathrm{~b}$ & $85.5 \pm 0.84 \mathrm{c}$ & 7.12 \\
\hline Total number of eggs/sac & $2.5 \pm 0.55 \mathrm{~b}$ & $3.5 \pm 0.55 a$ & $4.2 \pm 1.17 \mathrm{a}$ & 0.99 \\
\hline Number of eggs sac/ female & $14.74 .03 \mathrm{c}$ & $22.74 .93 \mathrm{~b}$ & $28.32 .66 \mathrm{a}$ & 4.9 \\
\hline
\end{tabular}

The means with the same letters at the same row are not significantly different at $0.05 \%$ level. 
Biological aspects of the true spider kochiura aulica (Araneida: Theridiidae) ......

\begin{tabular}{|c|c|c|c|c|c|c|c|c|c|c|c|c|c|}
\hline \multicolumn{3}{|c|}{ 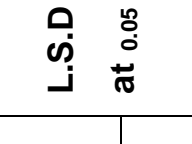 } & $\stackrel{\text { N̦ }}{\text { N }}$ & $\begin{array}{l}\text { గొ } \\
\text { Lొ }\end{array}$ & ब̆ & $\stackrel{\text { ̣̊̊ }}{\circ}$ & 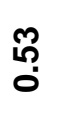 & $\stackrel{\vec{N}}{\boldsymbol{N}}$ & ঙ্লি & 궁 & חึ? & 占 & $\stackrel{\text { m్ }}{\text { in }}$ \\
\hline \multirow{3}{*}{ 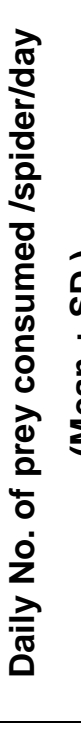 } & \multirow{3}{*}{ 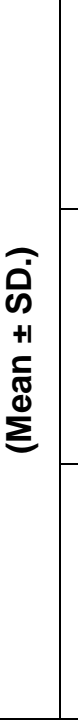 } & $\begin{array}{l}0 \\
\vdots \\
\text { ¿े }\end{array}$ & 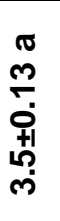 & 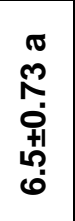 & $\begin{array}{l}\pi \\
\stackrel{-1}{7} \\
7 \\
-7 \\
+1 \\
+ \\
\infty\end{array}$ & 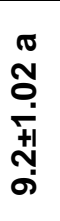 & 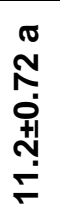 & 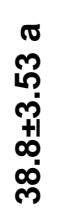 & 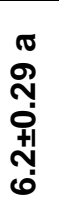 & 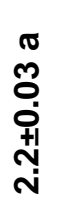 & $\begin{array}{l}\pi \\
8 \\
0 \\
0 \\
+1 \\
0 \\
10\end{array}$ & $\begin{array}{l}\pi \\
0 \\
0 \\
0 \\
+1 \\
0 \\
\dot{A}\end{array}$ & 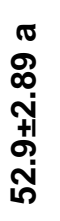 \\
\hline & & $\begin{array}{l}\text { U } \\
\text { in }\end{array}$ & 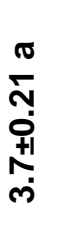 & $\begin{array}{l}\text { مी } \\
\text { N̦ } \\
\text { +1 } \\
\text { +1 } \\
\dot{f}\end{array}$ & 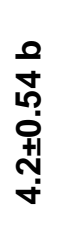 & $\begin{array}{l}0 \\
0 \\
0 \\
0 \\
01 \\
0 \\
0 \\
10\end{array}$ & 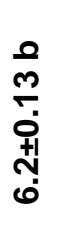 & 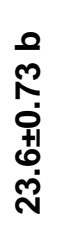 & \begin{tabular}{l}
0 \\
\multirow{N}{*}{} \\
0 \\
+1 \\
$+\dot{+}$
\end{tabular} & 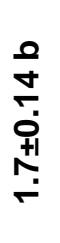 & 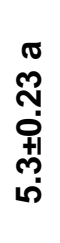 & 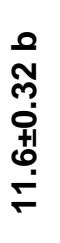 & 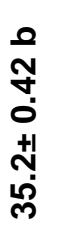 \\
\hline & & $\begin{array}{l}\text { Oे } \\
\text { ¿े }\end{array}$ & 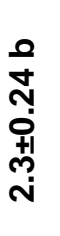 & 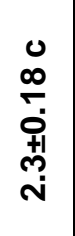 & 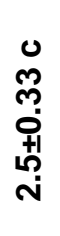 & 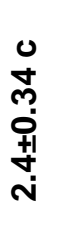 & 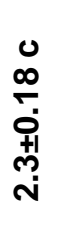 & 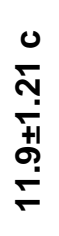 & 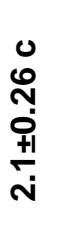 & 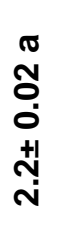 & 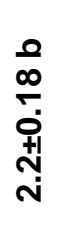 & \begin{tabular}{l}
0 \\
\multirow{N}{*}{} \\
0 \\
+1 \\
\multirow{0}{0}{}
\end{tabular} & 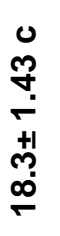 \\
\hline \multicolumn{3}{|c|}{$\begin{array}{ll}0 \\
ن\end{array}$} & 只 & 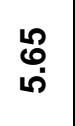 & $\frac{R}{N}$ & 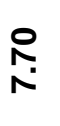 & $\begin{array}{l}\stackrel{\infty}{\infty} \\
\dot{f}\end{array}$ & $\begin{array}{l}\text { లి } \\
\text { N̦ }\end{array}$ & 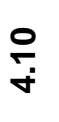 & $\begin{array}{l}\infty \\
\infty \\
\sigma 口\end{array}$ & $\underset{\infty}{\stackrel{N}{N}}$ & $\begin{array}{l}\text { ஃ } \\
\stackrel{9}{9}\end{array}$ & 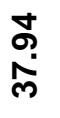 \\
\hline \multirow{3}{*}{\multicolumn{2}{|c|}{ 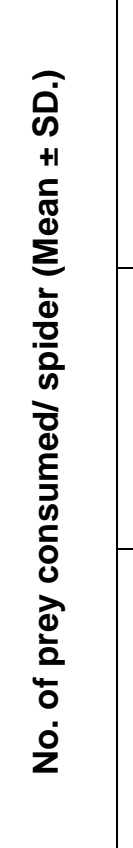 }} & $\begin{array}{l}\text { U } \\
\text { Oे }\end{array}$ & 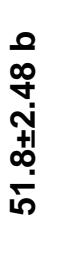 & \begin{tabular}{l}
$\sigma$ \\
$\infty$ \\
$o$ \\
+ \\
+1 \\
+1 \\
\multirow{1}{\infty}{}
\end{tabular} & 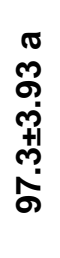 & 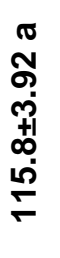 & 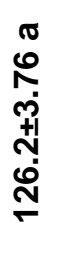 & 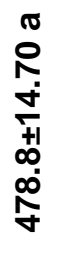 & 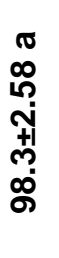 & 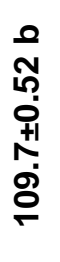 & 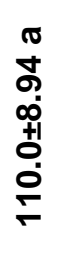 & 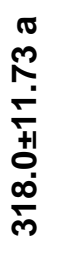 & 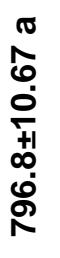 \\
\hline & & $\begin{array}{l}\text { ò } \\
\text { in }\end{array}$ & 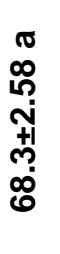 & $\begin{array}{l}0 \\
0 \\
0 \\
7 \\
10 \\
+1 \\
+1 \\
8\end{array}$ & $\begin{array}{l}0 \\
0 \\
0 \\
0 \\
0 \\
+1 \\
m \\
0 \\
0\end{array}$ & 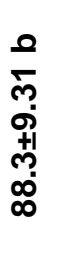 & $\begin{array}{l}0 \\
0 \\
\rightarrow 1 \\
\dot{p} \\
+1 \\
0 \\
0\end{array}$ & 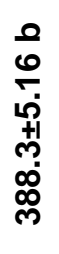 & 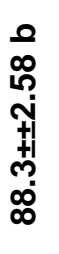 & 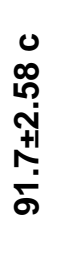 & 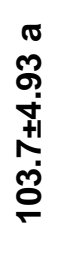 & 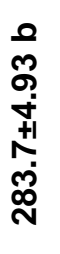 & 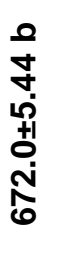 \\
\hline & & $\begin{array}{l}0 \\
\text { ¿े }\end{array}$ & \begin{tabular}{l}
0 \\
-1 \\
\\
0 \\
+1 \\
\multirow{1}{1}{} \\
in
\end{tabular} & 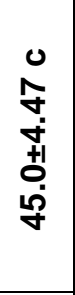 & 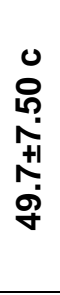 & 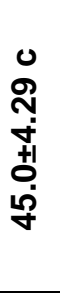 & 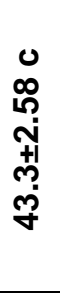 & 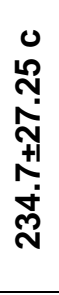 & 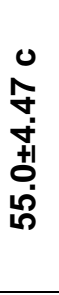 & 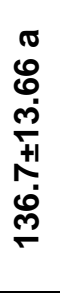 & 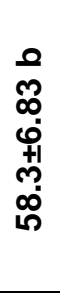 & 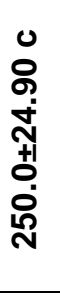 & 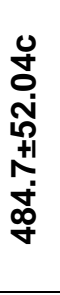 \\
\hline \multicolumn{3}{|c|}{ 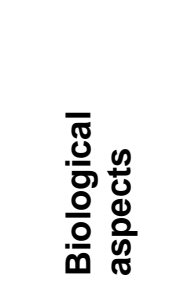 } & 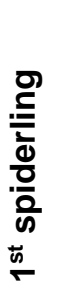 & 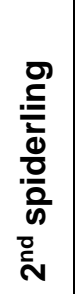 & 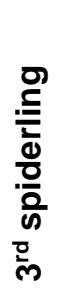 & 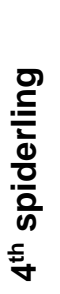 & 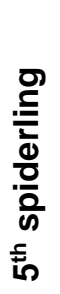 & 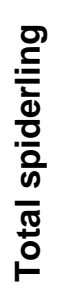 & 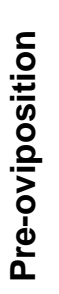 & 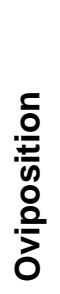 & 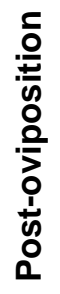 & 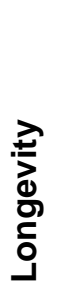 & 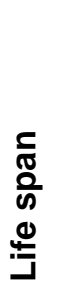 \\
\hline
\end{tabular}




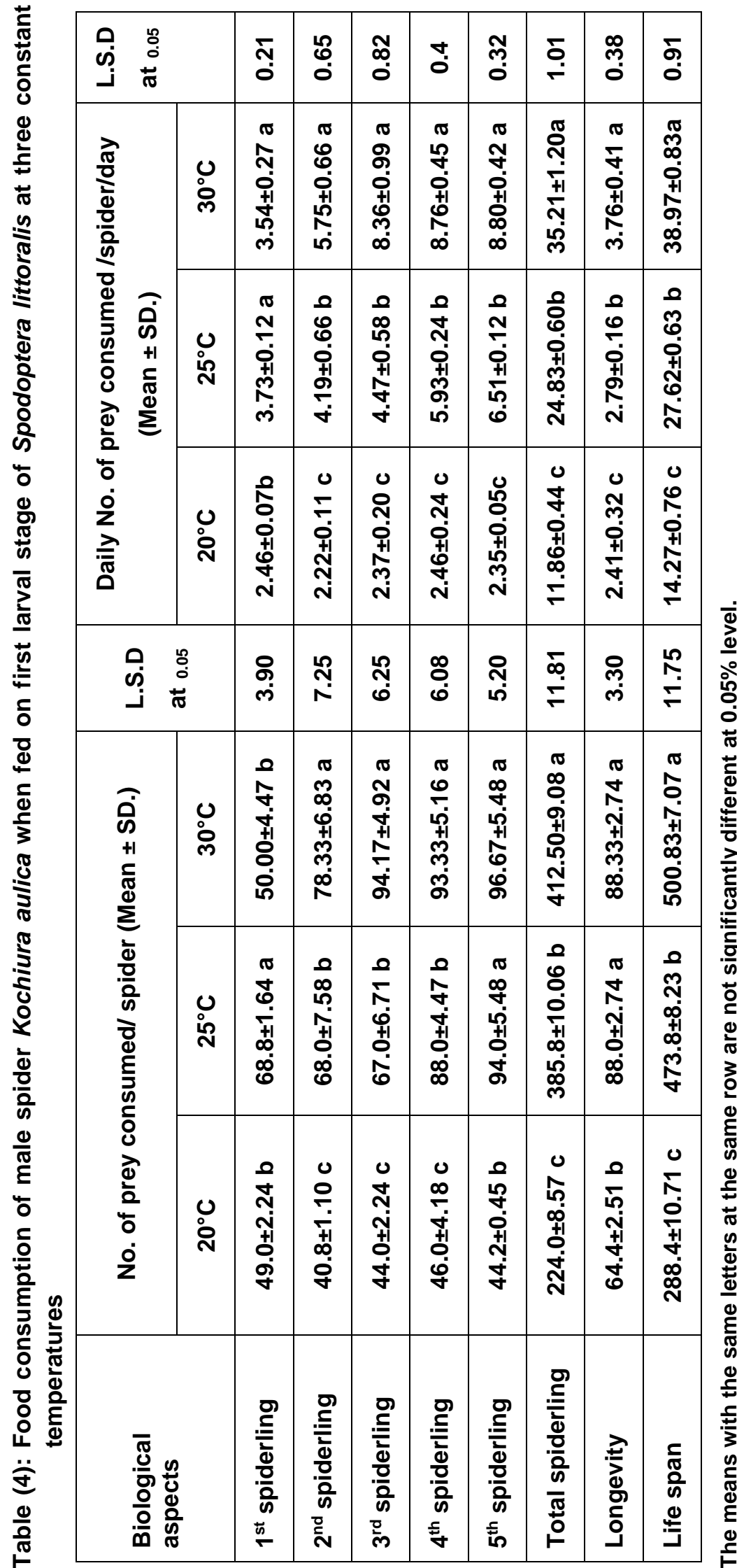




\section{REFERENCES}

Abdel-Azim, N.A. (2014). Rearing Theridion melanostictum O.P. Cambridge (Araneae: Theridiidae) on Tetranychus urticae Koch and larvae of Spodoptera littoralis Boisd. ACARINES, 8(2): 79-82.

Abdel-Karim, E.H., G.H. Rady, G.A. brahim and N.F. Ahmad (2006). Biology, mass rearing and observations on the behaviour of Kochiura aulica (C. L. Koch, 1838). Serket, 10(1): 35-43.

Abdel-Megeed, M.I. (1975). Field observations on the vertical distribution of the cotton leafworm, Spodoptera littoralis on cotton plants. Z. Angew Ent 78: 597-602.

Ahmad, N.F. and H.M. Heikal (2016). The biological characteristics study of the spider, Theridion spinitarse O. Pickard (Araneae: Theridiidae) in Egypt. Menoufia J. Plant Prot., 1(Aug.) 1-7.

Ahmad, N.F., G.A. Ibrahim, A.H. ElSherbeny and G.H. Rady (2009). Kochiura aulica (C. L. Koch, 1838) (Araneida: Theridiidae) against greenhouse pests. Serket, 11 (3/4): 102-109.

Ahmed, Naglaa, F. R. and A. S. Abd ElMaaboud (2014). Biological aspects of the spider Theridion incanescens (Araneae: Theridiidae) feeding on Tetranychus urticae and Ceratitis capitata with notes on its mating behaviour. Egypt. J. Biol., Sci., 7 (2):914.

Agnarsson I. (2004). Morphological phylogeny of cobweb spiders and their relatives (Araneae, Araneoidea, Theridiidae). Zoological Journal of the Linnean Society, 141(4): 447-626.

Coddington, J. A. and H. Levi (1991). Systematics and evolution of spiders (Araneae). Annual Review of Ecology, Evolution, and Systematics, 22: 565592.

El-Erksousy, M.H., A.A. Shoeib, and H.F. Dahi (2002). Studies on biological control using the spider Anelosimus oulicus (Theridiidae). $2^{\text {nd }}$ International
Conference, Plant Protection Research Institute, Cairo, Egypt, 1: 12.

El-Hennawy, H.K. (2002). A list of Egyptian spiders (revised in 2002). Serket, 8(2): 73-83.

Ghabbour S. I.; A. M. Hussein and H. K. El-Hennawy (1999). Spider populations associated with different crops in Menoufiya Governorate, Nile Delta, Egypt. Egypt. J. Agric. Res., 77 (3): 1163-1179.

Hussein, A.M., M.F. Hassan, and N.F.R. Ahmad (2003). Biological aspects of Anelosimus aulicus (C.L. Koch, 1838) (Arachnida: Araneida: Theridiidae) in Egypt. Serket, 8(4): 129-134.

Jeppson, T. R., S. D. Pollard, and S. S. Sadakathulla (1975). Studies uen dei coulation enhiemebe Epeiridern Zool., J.P. Syst., 631-643.

Mostafa, S. A. (1988). Effect of some insect growth regulators on some cotton pests. M. Sc. Thesis, Fac. Agric., Al- Azhar Univ. Egypt, 100 pp.

Rahil, A.A.R. and M.A. Hanna (2001). Some biological aspects of the true spider Anelosimus aulicus Koch (Theridiidae: Arachnida). Conference of Sustainable Agricultural Development, Fayoum Faculty of Agriculture, pp. 195-201.

Sallam, G.M.E. (2002). Survey and ecological studies on spiders in four governorates of Egypt. Serket, 8(1): 35-42.

Sallam, Gihan M.E. Nahla A.I.Abd El-Azim and M. A. Mohafez (2015). A study of some biological aspects of the spider Theridion jordanense Levy \& Amitai, 1982 (Araneae: Theridiidae) in Egypt. Egypt. Acad. J. Biolog. Sci., 8(1): 73 77.

SAS Institute. (2010). SAS Statistics and Graphics Guide, Release 9.1. SAS Institute, Cary, North Carolina, 275I3, USA.

World Spider Catalog. (2019). Natural History Museum Bern, online at http://wsc.nmbe.ch, version 20.0, accessed on [Accessed Feb. 2018]. 
المظاهر البيولوجية للعنكبوت Kochiura aulica (Araneida: Theridiidae) عند تغذيته على الطور اليرقى الأول لاودة ورق القطن فى مصر

$$
\text { آمال إبراهيم أبوزيد }
$$

معهل بحوث وقاية النباتات- مركز البحوث الززاعية- الدقي -جيزة مصر.

الملخص العربى

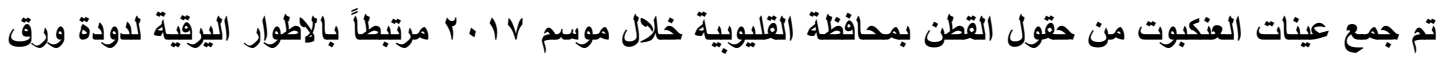
القطن. وجد ان العنكبوت Kochiura aulica (C.L. Koch, 1838 له خمسة أعمار يرقية للأكور والإناث. تم تربية

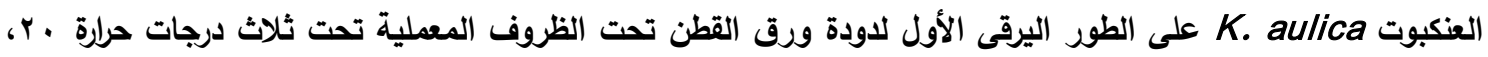

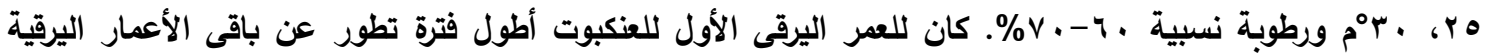

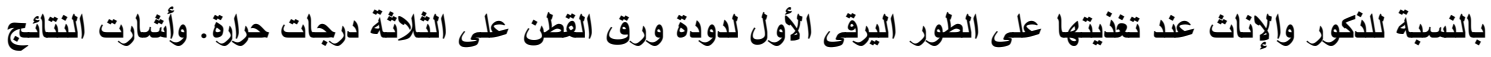

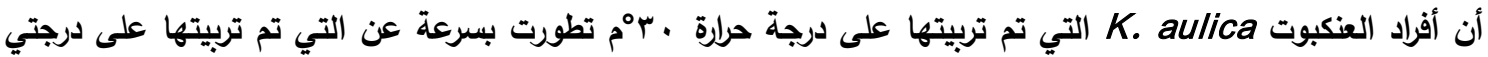

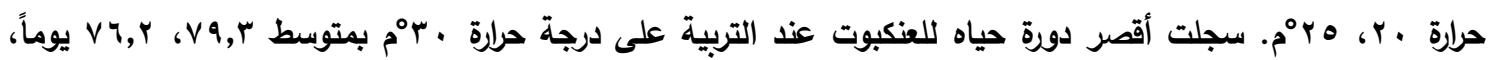

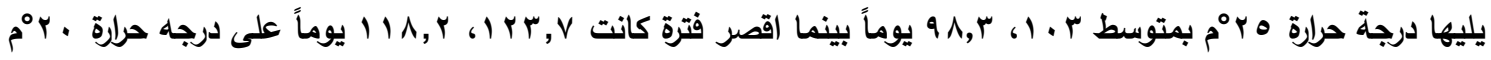
للإناث والذكور على التوالي مع وجود فروق معنوية بين الثلاثة درجات حرارة. تم حساب عداد الثرائس المستهلكة للأطوار

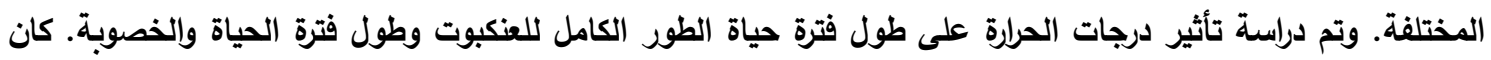

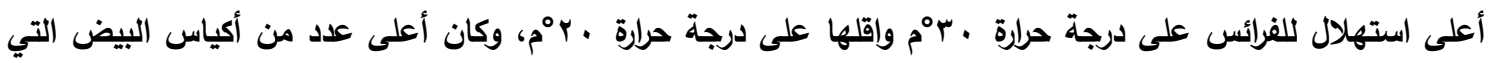

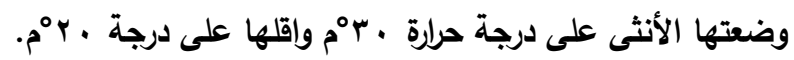

